\title{
Screening antimicrobial activity of various extracts of Urtica dioica
}

\author{
Amir Modarresi-Chahardehi ${ }^{1}$, Darah Ibrahim ${ }^{1}$, Shaida Fariza-Sulaiman ${ }^{2} \&$ Leila Mousavi $^{2}$ \\ 1. Industrial Biotechnology Research Laboratory, School of Biological Sciences, Universiti Sains Malaysia, 11800 \\ Minden, Penang, Malaysia; amirmch@yahoo.com,darah@usm.my \\ 2. Phytocemistry Laboratory, School of Biological sciences, Universiti Sains Malaysia, 11800 Minden, Penang, \\ Malaysia; shaida@usm.my, leila_mosavi12007@yahoo.com
}

Received 30-IX-2011. C Corrected 20-IV-2012. Accepted 21-V-2012.

\begin{abstract}
Urtica dioica or stinging nettle is traditionally used as an herbal medicine in Western Asia. The current study represents the investigation of antimicrobial activity of $U$. dioica from nine crude extracts that were prepared using different organic solvents, obtained from two extraction methods: the Soxhlet extractor (Method I), which included the use of four solvents with ethyl acetate and hexane, or the sequential partitions (Method II) with a five solvent system (butanol). The antibacterial and antifungal activities of crude extracts were tested against 28 bacteria, three yeast strains and seven fungal isolates by the disc diffusion and broth dilution methods. Amoxicillin was used as positive control for bacteria strains, vancomycin for Streptococcus sp., miconazole nitrate $(30 \mu \mathrm{g} / \mathrm{mL})$ as positive control for fungi and yeast, and pure methanol $(\mathrm{v} / \mathrm{v})$ as negative control. The disc diffusion assay was used to determine the sensitivity of the samples, whilst the broth dilution method was used for the determination of the minimal inhibition concentration (MIC). The ethyl acetate and hexane extract from extraction method I (EA I and HE I) exhibited highest inhibition against some pathogenic bacteria such as Bacillus cereus, MRSA and Vibrio parahaemolyticus. A selection of extracts that showed some activity was further tested for the MIC and minimal bactericidal concentrations (MBC). MIC values of Bacillus subtilis and Methicillin-resistant Staphylococcus aureus (MRSA) using butanol extract of extraction method II (BE II) were 8.33 and $16.33 \mathrm{mg} / \mathrm{mL}$, respectively; while the MIC value using ethyl acetate extract of extraction method II (EAE II) for Vibrio parahaemolyticus was $0.13 \mathrm{mg} / \mathrm{mL}$. Our study showed that $47.06 \%$ of extracts inhibited Gram-negative ( 8 out of 17 ), and $63.63 \%$ of extracts also inhibited Gram-positive bacteria (7 out of 11); besides, statistically the frequency of antimicrobial activity was $13.45 \%$ (35 out of 342 ) which in this among $21.71 \%$ belongs to antimicrobial activity extracts from extraction method I (33 out of 152 of crude extracts) and $6.82 \%$ from extraction method II (13 out of 190 of crude extracts). However, crude extracts from method I exhibited better antimicrobial activity against the Gram-positive bacteria than the Gram-negative bacteria. The positive results on medicinal plants screening for antibacterial activity constitutes primary information for further phytochemical and pharmacological studies. Therefore, the extracts could be suitable as antimicrobial agents in pharmaceutical and food industry. Rev. Biol. Trop. 60 (4): 1567-1576. Epub 2012 December 01.
\end{abstract}

Key words: Urtica dioica, antimicrobial activity, disc diffusion method, minimum inhibitory concentration (MIC), minimum bactericidal concentration (MBC).

Currently, research and development of new drugs from natural resources in a systematic and strategic manner has become the global trend. Natural product derived medicines are widely used and account for more than $30 \%$ of therapeutic agents presently prescribed in clinics (Yang et al. 2008). The activities have been selected because of their great medicinal relevance. Within the recent years, infections have increased to a great extent and resistance against antibiotics becomes an ever-increasing therapeutic problem (Austin et al. 1999). Because of the need for new antimicrobial agents and strategies for their use in the treatment of serious Gram-negative and Gram-positive infections is evident (Shah 2005, Gülçin et 
al. 2008, Gülçin et al. 2010) and is greater than ever because of the emergence of multidrug resistance in common pathogens, the rapid emergence of new infections, and the potential for use of multidrug-resistant agents in bioweapons (Spellberg et al. 2003).

Urtica L. Stinging nettle (Urticaceae) is annual and perennial herb, distinguished with stinging hairs. This plant is traditionally used in Morocco, Turkey, Brazil, Jordan and with much frequency in Northern Iran (Pourmorad et al., 2006). Among Urtica species, Urtica dioica and Urtica urens have already been known and therefore consumed for a long time as medicinal plants in many parts of the world (Chaurasia \& Wichtl 1987). U. dioica herbs are used to treat stomachache in Turkish folk medicine (Gulçin et al. 2004), and in Iran (Pourmorad et al. 2006, Monfared et al. 2011). Besides, this herb is used to treat rheumatic pain and for colds and cough (Sezik et al. 1997).

Plants are important sources of potentially useful structures for the development of new chemotherapeutic agents. The first step towards this goal is the in vitro antimicrobial activity assay (Saklani \& Chandra 2012). The main purpose of this study was to evaluate the antimicrobial activity of the various crude extracts of $U$. dioica and compare two methods of extraction and the ability of different kinds of $U$. dioica crude extracts to inhibit various pathogenic microorganisms.

\section{MATERIALS AND METHODS}

Preparation of the extract: The aerial parts of $U$. dioica including leaves and stems were collected in Iran from Salmanshahr city in Mazandaran province (the geographical coordinates given by GPS: latitude: $36^{\circ} 42$ ' $34^{\prime \prime} \mathrm{N}$ - 51 $08^{\prime} 57^{\prime \prime}$ E and altitude: $21 \mathrm{~m}$ ) and Tehran city in Tehran province (the geographical coordinates given by GPS: latitude: $35^{\circ} 50^{\prime} 21^{\prime \prime} \mathrm{N}$ - 51 $1^{\circ} 25^{\prime} 22^{\prime \prime}$ E and altitude: $2012 \mathrm{~m}$ ) in August 2007. The Voucher specimens were deposited at the Herbarium of the School of Pharmaceutical Sciences, University of Tehran (Iran) in April 2010 by the code of 6725-TEH. The plant materials were washed, dried and ground to small pieces. The first method of extraction (Method I) included the use of four solvents by following non-polar to polar solvents (by using Soxhlet apparatus). In this method, $100 \mathrm{~g}$ of dried plant material was wrapped properly in $24.0 \mathrm{~cm}$ Whatman No. 1 filter paper and placed in the extraction chamber. A total of $400 \mathrm{~mL}$ of hexane solvent was filled in the round flask. Both, the extraction chamber and the round flask were set below the condenser, respectively. The flask was heated to $40-45^{\circ} \mathrm{C}$ for $2-3$ days, consecutively. At the end of the extraction process, the solvent in the round flask was concentrated using rotary evaporator (Heidolph) and left to dryness in a fume cupboard. The residue of the dried sample was allowed to dry off before being extracted subsequently with other organic solvents (chloroform, ethyl acetate and methanol) with different polarity.

The second method (Method II) included a five solvent system (by using partition technique: separating funnel is a registered trademark of Aldrich ${ }^{\circledR} 500 \mathrm{~mL}$ ). For Method II, $100 \mathrm{~g}$ of dried sample was extracted in $500 \mathrm{~mL}$ of $100 \%$ methanol solvent by using the Soxhlet extractor for $72 \mathrm{hrs}$ at room temperature $\left(30 \pm 2^{\circ} \mathrm{C}\right)$. Then the mixture was filtered using muslin cloth and followed by $150 \mathrm{~mm}$ Whatman No. 1 filter paper. Approximately $300 \mathrm{~mL}$ of the methanol extract was concentrated with the rotary evaporator (Heidolph). Concentrated methanol extract obtained was left in fume cupboard to dryness. The remaining methanol extract (liquid form) at volume $200 \mathrm{~mL}$ was added with chloroform: distilled water (1:2) for further partitioning process. This mixture was carried out at volume $50 \mathrm{~mL}$ by three times (total up was $250 \mathrm{~mL}$ per times) in a separating funnel and shook slowly until two layers were formed. The bottom layer was collected as the residue (because density of chloroform is 1.498 and had high gravity than other solvent in this mixture). Aqueous layer was formed at upper layer and was collected for further partitioned with diethyl ether. Aqueous layer was added with diethyl ether (50mL in three times) as third solvent system for solvent- solvent 
partitioning. The upper layer was collected as diethyl ether fraction, while the aqueous layer at the bottom was collected as the residue. Subsequently, the aqueous residue formed was partitioned with ethyl acetate. The upper layer was collected as the ethyl acetate fraction while the bottom part was collected as the aqueous residue. The same partitioning process was repeated with butanol. All extracts were concentrated using the rotary evaporator and dried in the fume cupboard until they turned into paste form. At the end, the extracts obtained from this method were methanol extract, chloroform extract, diethyl ether extract, ethyl acetate extract and butanol extract as described by Mellidis \& Papageorgiou (1993). The dried extracts were then weighed using microbalance and were kept in $4^{\circ} \mathrm{C}$. Crude extracts used in this study were coded as follows: HE I (hexane extract of method I), CE I (chloroform extract of method I), EAE I (ethyl acetate extract of method I), ME I (methanol extract of method I), ME II (methanol extract of method II), CE II (chloroform extract of method II), DEE II (diethyl ether extract of method II), EAE II (ethyl acetate extract of method II) and BE II (butanol extract of method II).

Antimicrobial activity test: Antimicrobial activity was determined by using Disc Diffusion following the method described by the National Committee for Clinical Laboratory Standard (NCCLS) (2002). All bacterial strains including American Type Culture Collection (ATCC) and clinical were used in the study. The test bacteria was removed aseptically with an inoculating loop and transferred to a test tube containing $5 \mathrm{~mL}$ of sterile distilled water. Sufficient inoculums were added until the turbidity equaled $0.5 \mathrm{McFarland}\left(10^{8} \mathrm{cfu} /\right.$ $\mathrm{mL}$ ) standards (bioMerieux, Marcy d'Etoile, France). The test tube suspension $(1 \mathrm{~mL})$ was added to $15-20 \mathrm{~mL}$ of nutrient agar or Sabouraud dextrose agar, before setting aside the seeded agar plate $(9 \mathrm{~cm}$ in diameter) to solidify for $15 \mathrm{~min}$. Three disks of Whatman's No. 1 filter paper, $6 \mathrm{~mm}$ in diameter, were used to screen the antimicrobial activity. Each sterile disk was impregnated with $20 \mu \mathrm{L}$ of extract (corresponding to $100 \mathrm{mg}$ of crude extract/ $\mathrm{mL}$ ), Amoxicillin was used as positive control for bacteria and vancomycin for Streptococcus sp. or miconazole nitrate $(30 \mu \mathrm{g} / \mathrm{mL})$ as positive control for fungi, or pure methanol (v/v) (as negative control), before it was placed on the surface of the seeded plates. Then, the plates of bacterial and yeasts were incubated at $37^{\circ} \mathrm{C}$ overnight (18-24 hrs) and $24-48 \mathrm{hrs}$, respectively, whereas the fungal plates were incubated at $30^{\circ} \mathrm{C}$ for $24-72 \mathrm{hrs}$. At the end of the incubation period the antimicrobial activity was evaluated by measuring the clear inhibition zones formed around the discs (diameter of inhibition zone plus diameter of the disc).

To calculate of percentage of antimicrobial activity, number of effective crude extract or number of tested microorganism were divided on total of selected microorganisms. We compared both methods of extraction (Method I and II), and between Gram-negative and Grampositive bacteria.

Determination of the minimum inhibitory concentration (MIC): MIC was determined by the liquid dilution method. Dilution series were set up with $0.13,0.26,0.52,1.04,2.08$, $4.16,8.33,16.66,33.33,66.66$ and $133.33 \mathrm{mg} /$ $\mathrm{mL}$ of nutrient broth medium. Each test tube was added with $0.5 \mathrm{~mL}$ of standardized suspension of bacteria and incubated at $37^{\circ} \mathrm{C}$ for 24 hours. The lowest dilution of the extract that retained its inhibitory effect resulting in no growth (absence of turbidity) of a microorganism was recorded as the MIC value of the extract. The microorganism growth was indicated by the turbidity. A control experiment was run in parallel to study the impact of the solvent itself on the tested organism growth. The tests were performed in triplicate.

Determination of the minimum bactericidal concentration (MBC): The minimum bactericidal concentration of the plant extract on the clinical bacterial isolates was done according to the method highlighted in NCCLS (2002). Briefly, one loopful of the inoculums 
from each of the non-turbid tubes was streaked on to NA plate and incubated at $37^{\circ} \mathrm{C}$ for 24 hrs. The lowest concentration at which there was no visible growth was regarded as the MBC value after overnight incubation. After the incubation period, the plates were examined for the growth of a bacterium to determine the concentration of the extract at which $99.9 \%$ killing bacterial isolates was achieved.

\section{RESULTS}

The results of the antimicrobial activity tests of crude extracts are shown in table 1. It was found that nine crude extracts of Urtica dioica at $100 \mathrm{mg} / \mathrm{mL}$ concentration exhibited various antibacterial and antimycotic activities but no antifungal activity.

Urtica dioica extracts gave large inhibition zone to Acinetobacter calcoaceticus, Bacillus cereus, B. spizizenii ATCC 6633, Micrococcus sp. and Vibrio parahaemolyticus. According to table 1, BE II was effective against Escherichia coli, B. subtilis and methicillin resistant Staphylococcus aureus (MRSA). Among the Gram-negative bacteria tested, Klebsiella pneumonia, E. coli, Salmonella paratyphy B showed exhibited zoned of inhibition less than $9 \mathrm{~mm}$ in diameter. However, some of the Grampositive bacteria such as $B$. cereus, $B$. spizizenii ATCC 6633 and V. parahaemolyticus exhibited zones of inhibition between 10 and $14 \mathrm{~mm}$ in diameter. The mold, Saccharomyces cerevisiae was found with zones of inhibition from 9 to $10-14 \mathrm{~mm}$. Nevertheless, the results seem to indicate that method I (Soxhlet extractor) may be more effective than method II (using sequential partitions). This reason may be related to the extracting method from nonpolar to polar components.

All the extracts failed to inhibit the mold, except all crude extract from extraction method I against $S$. cerevisiae. Also Aspergillus niger USM A1 and Trichophyton rubrum showed reduced of UFC, but nor hypha. In addition, pure methanol (control) had no inhibitory effects on pathogenic microbes tested.
The MIC values of the crude extracts of $U$. dioica were determined against bacterial species that showed positive results in the antimicrobial activity tests and are presented in table 2. The agar dilution method showed MIC values of 0.13 to $66.66 \mathrm{mg} / \mathrm{mL}$. The broader spectrum of activities could be due to synergistic effects of the various components in the U. dioica extract. EAE II and CE I showed the lowest concentration of MIC values of 0.13 and $4.16 \mathrm{mg} / \mathrm{mL}$, respectively, against $V$. parahaemolyticus. The antimycotic activity against $S$. cerevisiae of ethyl acetate extract from method I (EAE I) was also strong with MIC and MBC values of 2.08 and $8.33 \mathrm{mg} / \mathrm{mL}$, respectively.

In this study a $47.06 \%$ of extracts inhibited Gram-negative (eight out of 17) and $63.63 \%$ of extracts also inhibited Gram-positive bacteria (seven out of 11) and the frequency of antimicrobial activity statically was $13.45 \%$ (35 out of 342 ) which in this among $21.71 \%$ belongs to antimicrobial activity extracts from extraction method I (33 out of 152 of crude extracts) and $6.82 \%$ from extraction method II (13 out of 190 of crude extracts).

According to antimicrobial activity of Urtica dioica as shown in figure 1, EAE I $>$ HE I $>$ CE $\quad$ I $>$ ME $\quad$ I $>$ CE $\quad$ II $=$ DEUD $\quad$ II $=$ BE $\quad$ II $>$ ME II=EAE II showed level of high antimicrobial activity, respectively. We may conclude that the antimicrobial activity of crude extracts of $U$. dioica, ethyl acetate extract from extraction method I (EAE I) showed the highest antimicrobial activity with more than $25 \%$. In fact, $10.46 \%$ (16 out of 153 ) and $22.22 \%$ (22 out of 99) of extracts inhibited of Gram-negative and Gram- positive bacteria, respectively. However, EAE I showed high frequency of inhibition of growth of bacteria. Crude extracts of $U$. dioica exhibited poor antibacterial activity against Pseudomonas and Staphylococcus spp. and fungicidal activity was not observed.

\section{DISCUSSION}

The results suggest that $U$. dioica exhibits bactericidal and mycoticidal activities. The resistance of fungal species against the crude 
TABLE 1

Antimicrobial activities of the various extracts of Urtica dioica

\begin{tabular}{|c|c|c|c|c|c|c|c|c|c|}
\hline Pathogenic microorganism & HE I & CE I & EAE I & ME I & ME II & CE II & DE II & EAE II & BE II \\
\hline \multicolumn{10}{|l|}{ Bacteria } \\
\hline \multicolumn{10}{|l|}{ Gram-negative: } \\
\hline Acinetobacter calcoaceticus & - & - & - & - & ++ & +++ & + & - & - \\
\hline A. anitratus & - & - & - & - & - & - & - & - & - \\
\hline Borkholderia pseudomallei & - & - & - & - & - & - & - & - & - \\
\hline Citrobacter freundii & - & - & - & - & + & - & - & - & - \\
\hline Entrobacter aerogenes & - & - & - & - & - & - & - & + & - \\
\hline Escherichia coli & - & - & - & - & - & - & + & - & + \\
\hline Erwinia sp. & - & + & + & + & - & - & - & - & - \\
\hline Klebsiella pneumoniae & + & - & + & + & - & - & - & - & - \\
\hline K. pneumoniae ATCC 13883 & - & - & - & - & - & - & - & - & - \\
\hline Pseudomonas aeruginosa ATCC 27853 & - & - & - & - & - & - & - & - & - \\
\hline P. stutzeri ATCC 17588 & - & - & - & - & - & - & - & - & - \\
\hline Salmonella paratyphi B & - & + & + & - & - & - & - & - & - \\
\hline Serratia marcescns & - & - & - & - & - & + & - & - & - \\
\hline Shigella boydii ATCC 9207 & - & - & - & - & - & - & - & - & - \\
\hline Morganella morganii & - & - & - & - & - & - & - & - & - \\
\hline Streptococcus salivarius ATCC 13419 & - & - & - & - & - & - & - & - & - \\
\hline Yersinia sp. & - & - & - & - & - & - & - & - & - \\
\hline \multicolumn{10}{|l|}{ Gram-positive: } \\
\hline Bacillus cereus & ++ & + & + & + & - & - & - & - & - \\
\hline B. cereus ATCC 10876 & + & + & + & - & - & - & - & - & - \\
\hline B. subtilis & - & - & - & - & - & - & + & - & + \\
\hline B. licheniformis ATCC 14580 & - & - & - & - & - & - & - & - & - \\
\hline B. spizizenii ATCC 6633 & ++ & + & ++ & + & - & - & - & - & - \\
\hline Staphylococcus aureus & - & - & - & - & - & - & - & - & - \\
\hline S. aureus ATCC 12600 & - & - & - & - & - & - & - & - & - \\
\hline S. epidermidis ATCC 1228 & - & - & - & - & - & - & - & - & - \\
\hline Methicillin-resistant Staphylococcus aureus (MRSA) & + & - & - & - & - & - & - & - & + \\
\hline Micrococcus sp. & ++ & - & ++ & - & - & + & - & - & - \\
\hline Vibrio parahaemolyticus & ++ & ++ & ++ & - & - & - & - & ++ & - \\
\hline \multicolumn{10}{|l|}{ Yeast } \\
\hline Candida albicans & - & - & - & - & - & - & - & - & - \\
\hline C. utilis & - & - & - & - & - & - & - & - & - \\
\hline Saccharomyces cerevisiae & + & ++ & ++ & + & - & - & - & - & - \\
\hline \multicolumn{10}{|l|}{ Fungi } \\
\hline Aspergillus flavus & - & - & - & - & - & - & - & - & - \\
\hline A. fumigatus & - & - & - & - & - & - & - & - & - \\
\hline A. niger USM AI1 & $-*$ & - & - & - & - & - & - & - & - \\
\hline Penicillium sp. & - & - & - & - & - & - & - & - & - \\
\hline Rhizopus sp. & - & - & - & - & - & - & - & - & - \\
\hline Trichophyton rubrum & - & $-*$ & $-*$ & $-*$ & - & - & - & - & - \\
\hline Trichoderma viridae & - & - & - & - & - & - & - & - & - \\
\hline
\end{tabular}

Antimicrobial activity based on the diameter of inhibition zone $(\mathrm{mm})$ follow this skim: $+++\geq 15 \mathrm{~mm},++10-14 \mathrm{~mm},+\leq 9 \mathrm{~mm}$. * Extract showed reduced of inoculums but not hypha.

HE I=hexane extract of method I, CE I=chloroform extract of method I, EAE I=ethyl acetate extract of method I, ME I=methanol extract of method I, ME II=methanol extract of method II, CE II=chloroform extract of method II, DEE $\mathrm{II}=$ diethyl ether extract of method II, EAE II=ethyl acetate extract of method II and BE II=butanol extract of method II. 
TABLE 2

In vitro activity of pathogenic microbial for MIC and $\mathrm{MBC}$ values $(\mathrm{mg} / \mathrm{mL})$

\begin{tabular}{clcc} 
Crude plant extract & \multicolumn{1}{c}{ Bacteria } & MIC value $(\mathrm{mg} / \mathrm{mL})$ & MBC value $(\mathrm{mg} / \mathrm{mL})$ \\
HE I & MRSA & 66.66 & 133.33 \\
HE I & Bacillus cereus & 16.66 & 33.33 \\
HE I & B. spizizenii ATCC 663 & 16.66 & 33.33 \\
HE I & Vibrio parahaemolyticus & 66.66 & 133.33 \\
CE I & B. cereus & 33.33 & 66.66 \\
CE I & V. parahaemolyticus & 4.16 & 8.33 \\
EAE I & B. spizizenii ATCC 663 & 8.33 & 16.66 \\
EAE I & V. parahaemolyticus & 16.66 & 33.33 \\
EAE I & Saccharomyces cerevisiae & 2.08 & 8.33 \\
ME II & Acinetobacter calcoaceticus & 16.66 & 33.33 \\
CE II & A. calcoaceticus & 33.33 & 66.66 \\
EAE II & V. parahaemolyticus & 0.13 & 0.13 \\
BE II & Escherichia coli & 66.66 & 133.33 \\
BE II & B. subtilis & 8.33 & 16.66 \\
BE II & MRSA & 16.66 & 33.33 \\
\hline
\end{tabular}

HE I=hexane extract of method I, CE I=chloroform extract of method I, EAE I=ethyl acetate extract of method I, ME $\mathrm{II}=$ methanol extract of method II, CE II=chloroform extract of method II, EAE II=ethyl acetate extract of method II and BE $\mathrm{II}=$ butanol extract of method II.

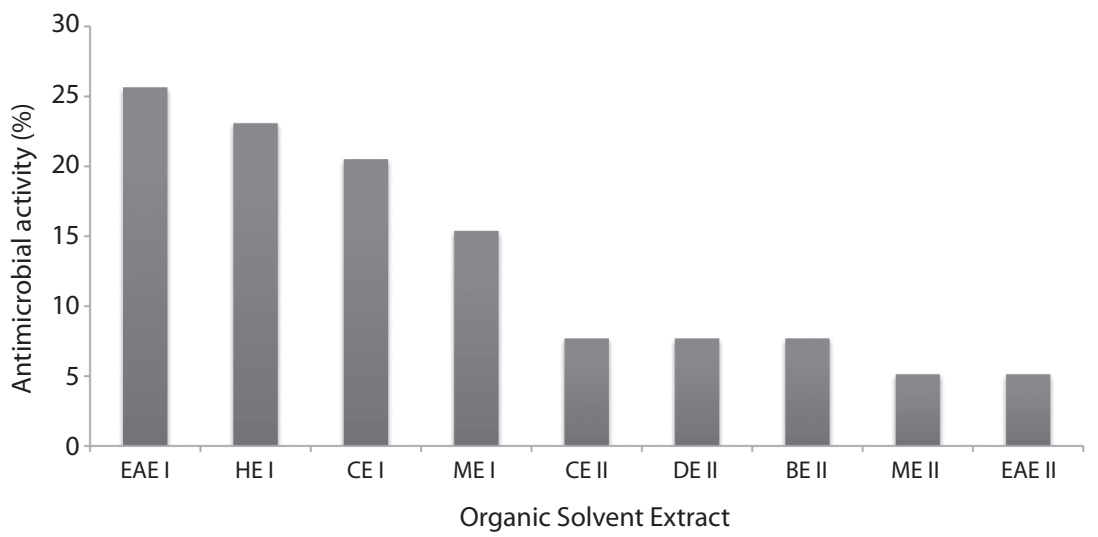

Fig. 1. Antimicrobial and antibacterial activities for different organic extracts of Urtica dioica. The effect of organic solvent extracts on antimicrobial activity.

extracts of $U$. dioica could be due to their morphological structure; fungi have thicker cell walls and contain higher percentage of chitin (Madigan \& Martinko 2006). Furthermore, the pathogenic microorganisms showed relatively lower MIC values ranging from 0.130 to $66.66 \mathrm{mg} / \mathrm{mL}$. However, in the present study lower activity of Method I was observed against Gram-positive bacteria (Bacillus cereus, Micrococcus sp.), while relatively less antibacterial activity was associated with Gram-negative bacteria. The review by Pellecuer et al. (1976) showed that phenolics are the predominant active compound in some family plants, with Gram-positive bacteria being the most sensitive germs. 
The different crude extract preparations revealed different spectrums of activities, especially with the use of the disc diffusion method. Otshudi et al. (1999) indicated that diethyl ether extracts of plants were inactive against bacteria compared to aqueous methanol extracts. It was clearly stated that plants contained microbial inhibitors (i.e., flavonoids) soluble in aqueous methanol, and the flavonoid aglycones were more active than their glycosidic forms naturally present in plants (Rauha et al. 2000). This reason may slightly explain why the broad inhibitory activity of diethyl ether extract on Method II (DEE II) was poor when compared with the two kinds of methanol extracts from both methods (ME I and ME II). According to our results, ethyl acetate, hexane and chloroform extracts showed higher antimicrobial activity than the other crude extracts. Some studies found that chloroform results better than methanol and benzene (Sastry \& Rao 1994). The different crude preparations showed different spectrum of activities, especially by the disk diffusion method (Sasidharan et al. 2009).

A large zone of inhibition was observed against $A$. calcoaceticus (chloroform extract of Method II), but with an MIC value of $33.33 \mathrm{mg} /$ $\mathrm{mL}$ or less, there was no inhibition found from Method I. Disc diffusion method in this study was used to detect the antimicrobial activity of crude extracts and not to determine and quantify the extracts. The $U$. dioica also could be used to treat $V$. parahaemolyticus, B. cereus, $S$. aureus and methicillin-resistant $S$. aureus (MRSA) infections. As it is well known, MRSA, E. coli and Bacillus species, especially B. cereus, are agents of food poisoning. The most interesting area of application for plant extracts is the inhibition of growth and reduction in numbers of the more serious food-borne pathogens (Burt 2004). B. cereus and B. subtilis are responsible for a minority of foodborne illnesses causing severe nausea, vomiting and diarrhea, could be treated with hexane extract of method I (HE I) and butanol extract of method II (BE II), as the MIC value for both bacteria were $8.33 \mathrm{mg} /$ $\mathrm{mL}$. In this case, further testing is needed to determine the effectiveness of the HE I and BE II on toxicity assay of these extracts for using pharmaceutical and food industries and due to achieve to pure bioactive components. The increasing of antimicrobial activity in extraction method I can be seen from methanol as polar solvent to hexane as non-polar solvent except among them ethyl acetate which showed high antimicrobial activity.

Gulçin et al. (2004) found some antimicrobial activity of the $U$. dioica water extract against E. coli, Enterobacter aerogenes, $S$. epidermidis and Candida albicans, while there was no activity against Pseudomonas aeruginosa. Their results were in agreement with our findings. Also Mothana et al. (2008) found that methanol extract of Forrskalea tinacissima other species in this family had low antibacterial activity against $S$. aureus and Microccus flavus, but no activity against $B$. cereus and $E$. coli. As the same result from Pilea microphylla (Urticaceae family) had low antibacterial activity against $S$. aureus by using mixture of acetone and ethyl acetate (Facey et al. 1999), and recent study have reported on the antibacterial activity of extracts from $P$. microphylla on Gram-positive bacteria such as B. cereus, B. subtilis and Methicillin resistant $S$. aureus (Modarresi-Chahardehi et al. 2010).

A study reported that Urera baccifera from Urticaceae showed no antimicrobial activity against $C$. albicans, E. coli, $P$. aeruginosa and $S$. aureus. Also the extracts of $U$. dioica showed no antimicrobial effects against the tested microorganisms in this study (Caceres et al. 1987). The $80 \%$ ethanol extract of $U$. dioica did not show any inhibition zone against the tested bacteria (Dulger \& Gonuz 2004). In other study, Steenkamp et al. (2004) confirmed that various studies support their results which U. urens possess no antibacterial activity (Rabe \& van Staden 1997, Dulger \& Gonuz 2004). Also in study by Pérez \& Anesini (1994), for screening antibacterial activity of Argentine folk medicinal plants against Salmonella typhi, antimicrobial equivalence from $U$. urens obtained $15.5 \pm 0.0 \mathrm{~mm}$. The antimicrobial activity was evaluated by measuring the inhibition 
zone diameter observed at $48 \mathrm{hrs}$. The mean values were interpolated by comparison to a reference concentration-response curve of ampicillin. Antimicrobial equivalence of $U$. urens was still low compared to other plant tested in other family (ranging from $9.8 \pm 0.4$ to $73.4 \pm 19.6 \mathrm{~mm})$.

In contrast to the Rabe \& van Staden (1997) report, methanol and also water extracts from root part of Pouzolzia mixta, that belongs to Urticaceae family, showed less antibacterial activity against $S$. aureus, $S$. epidermis and B. subtilis. However, MIC values against these bacteria were 4.0, 2.0 and $2.0 \mathrm{mg} / \mathrm{mL}$, respectively.

Generally, crude extracts from Method I showed better antimicrobial activity against the Gram-positive bacteria than the Gram-negative bacteria. The resistance of Gram-negative bacteria towards antibacterial agents is related to lipopolysaccharides in their outer membrane (Sawer et al. 1997, Gao et al. 1999). Grampositive bacteria, B. cereus, MRSA, were most susceptible to the crude extract of Method I, but it can be hypothesized that the effects of the extract were exerted on the outer membrane of the cell wall which then altered the membrane structure and permeability of the cell. The changes of the membrane structure might be resulted from the breakage of the hydrogen bonds that functions in keeping the rigidity of the membrane (Zhao et al. 2003, Darah et al. 2011). To state that the reason Grampositive bacteria are susceptible to the crude extract is related to the extraction method. It is a proven fact that Gram-positive bacteria are more susceptible to extracts than their Gram-Negative counterparts.

Extracts of ethyl acetate, hexane from extraction method I and butanol from extraction method II of $U$. dioica were found to be effective against some of strains studied. In addition, is the fact that the ethyl acetate extract from extraction method I showed good inhibitory effect on growth of pathogenic bacteria. It may be suggested from the findings that both extracts can be used a potential source of natural antimicrobial compound. Further research is needed for the identification of bioactive compounds and also the in vivo evaluation of antimicrobial activity, along with toxicity assays, present in the two extracts before it is used for commercialization in the form of pharmaceutical medicine.

\section{ACKNOWLEDGMENTS}

This material is based upon work supported by a grant and fellowship obtained from Universiti Sains Malaysia (USM).

\section{RESUMEN}

Urtica dioica $\mathrm{u}$ ortiga se utiliza tradicionalmente como medicina herbaria en el oeste de Asia. En esta investigación se estudia la actividad antimicrobiana de nueve extractos crudos de $U$. dioica, los cuales fueron preparados utilizando diferentes disolventes orgánicos y obtenidos a partir de dos métodos de extracción: el extractor Soxhlet (Método I), que incluía el uso de cuatro disolventes con acetato de etilo y hexano, y las particiones secuenciales (Método II) con un sistema de cinco disolventes (butanol). Las actividades antibacterianas y antifúngicas de extractos crudos fueron ensayados contra 28 bacterias, tres cepas de levadura y siete cepas fúngicas por la difusión en disco y el método de dilución en caldo. La amoxicilina se utilizó como control positivo para cepas de bacterias, vancomicina para Streptococcus sp., nitrato de miconazol $(30 \mu \mathrm{g} / \mathrm{mL})$ como control positivo para los hongos y levaduras, y el metanol puro (v/v) como control negativo. El ensayo de difusión en disco se utilizó para determinar la sensibilidad de las muestras, mientras que el método de dilución en caldo se utilizó para la determinación de la concentración de inhibición mínima (CIM). El acetato de etilo y el extracto de hexano del método de extracción I (AE I y EH I) mostraron mayor inhibición contra algunas bacterias patógenas tales como Bacillus cereus, MRSA y Vibrio parahaemolyticus. Una selección de extractos que mostraron algún tipo de actividad se probó para el CIM y las concentraciones mínimas bactericidas (CMB). Los valores de CIM de Bacillus subtilis y de Staphylococcus aureus resistentes a la meticilina (MRSA) usando extracto de butanol mediante el método de extracción II (EB II) fueron: 8.33 y $16.33 \mathrm{mg}$ / $\mathrm{mL}$, respectivamente; mientras que el valor de MIC con el uso del extracto de acetato de etilo por el Método de extracción II (EAE II) para Vibrio parahaemolyticus fue $0.13 \mathrm{mg} / \mathrm{mL}$. Nuestro estudio mostró que el $47.06 \%$ de los extractos inhibieron bacterias Gram-negativas ( 8 de 17), y el $63,63 \%$ de los extractos también inhibieron bacterias Gram-positivas (7 de 11), además que estadísticamente la frecuencia de la actividad antimicrobiana fue de $13.45 \%$ (35 de 342 ), que de este porcentaje un $21.71 \%$ pertenece a 
los extractos de actividad antimicrobiana con el método de extracción I (33 de 152 de los extractos crudos) y un $6.82 \%$ del método de extracción II (13 de 190 de los extractos crudos). Sin embargo, los extractos crudos del método I exhibieron una mejor actividad antimicrobiana contra las bacterias Gram-positivas que las Gram-negativas. Los resultados positivos en la detección de plantas medicinales para la actividad antibacteriana constituye información primaria para la realización de nuevos estudios fitoquímicos y farmacológicos. Por lo tanto, los extractos podrían ser adecuados como agentes antimicrobianos en la industria farmacéutica y de alimentos.

Palabras clave: Urtica dioica, actividad antimicrobiana, método de difusión en disco, concentración mínima inhibitoria (CMI), concentración bactericida mínima (CBM).

\section{REFERENCES}

Austin, D.J., K.G. Kristinsson \& R.M. Anderson. 1999. The relationship between the volume of antimicrobial consumption in human communities and the frequency of resistance. Proc. Natl. Acad. Sci. USA 96: 1152-1156.

Burt, S. 2004. Essential oils: Their antibacterial properties and potential applications in foods-A review. Int. J. Food Microbiol. 94: 223-253.

Caceres, A., L.M. Giron, S.R. Alvarodo \& M.F. Torres. 1987. Screening of antimicrobial activity of plants populary used in Guatemala for the treatment of dermatomucosal disease. J. Ethnopharmacol. 20: 223-237.

Chaurasia, N. \& M. Wichtl. 1987. Flavonol glycosides aus Urtica dioica. Planta Med. 53: 432-434.

Darah, I., C.L. Lim, Z. Nurul-Aili, S. Nor-Afifah \& S. Shaida-Fariza. 2011. Effects of methanolic extract of a soft sponge, Haliclona sp. on bacterial cells: structural degeneration study. Int. J. Comprehensive Pharm. 2: 1-6.

Dulger, B. \& A. Gonuz. 2004. Antimicrobial activity of certain plants used in Turkish traditional medicine. Asian J. Plant Sci. 3: 104-107.

Facey, P.C., K.O. Pascoe, R.B. Porter \& A.D. Jones. 1999. Investigation of plants used in Jamaican folk medicine for anti-bacterial activity. J. Pharm. Pharmacol. 51: 1455-1460.

Gao, Y., M.J.V. Belkum \& M. Stiles. 1999. The outer membrane of Gram-negative bacteria inhibits antibacterial activity of Brochocin C. Appl. Environ. Microbiol. 65: 4329-4333.

Gulçin, İ., İ. Küfrevioğlu, M. Oktay \& M.E. Büyükokuroğlu. 2004. Antioxidant, antimicrobial, antiulcer and analgesic activities of nettle (Urtica dioica L.). J. Ethnopharmacol. 90: 205-215.
Gulçin, İ., A. Zafer-Tel \& E. Kirecci. 2008. Antioxidant, antimicrobial, antifungal and antiradical activities of Cyclotrichium niveum (Boiss.) Manden and Scheng. Int. J. Food Properties 11: 450-471.

Gülçin, İ., E. Kireçci, E. Akkemik, F. Topal \& O. Hisar. 2010. Antioxidant and antimicrobial activities of an aquatic plant: Duckweed (Lemna minor L.). Turkish J. Biol. 34: 175-188. .

Madigan, M.T. \& J.M. Martinko. 2006. Brock Biology of Microorganisms. Pearson-Prentice Hall, Upper Saddle River, New Jersey, USA.

Mellidis, A.S. \& V.P. Papageorgiou. 1993. Phenolic constituents from Onosma heterophylla. J. Nat. Prod. 56: 949-952.

Modarresi-Chahardehi, A., D. Ibrahim \& S. Fariza-Sulaiman. 2010. Antioxidant, antimicrobial activity and toxicity test of Pilea microphylla. Int. J. Microbiol. 2010: 1-6.

Monfared, M., A. Kamkar, S. Ghaffari-Khaligh, A. JebelliJavan, F. Asadi \& A. Akhundzadeh-Basti. 2011. Antioxidative effects of Iranian Urtica dioica L. extracts on the oxidation of sunflower oil. J. Med. Plants Res. 5: 4438-4445.

Mothana, R.A.A., S.A.A. Abdo, S. Hasson, F.S.A.Z. Alaghbari \& U. Lindequist. 2008. Antimicrobial, antioxidant and cytotoxic activities and phytochemical screening of some Yemeni medicinal plants. Evid-Based Compl. Alt. Med. 7: 323-330.

National Committee for Clinical Laboratory Standards (NCCLS). 2002. Methods for Dilution Antimicrobial Susceptibility Tests for Bacteria that Grow Aerobically; Approved Standard. National Committee for Clinical Laboratory Standards, Wayne, Pennsylvania, USA.

Otshudi, A.L., A. Foriers, A. Vercruysse, A. Van Zeebroeck \& S. Lauwers. 1999. In vitro antimicrobial activity of six medicinal plants traditionally used for the treatment of dysentery and diarrhoea in Democratic Republic of Congo (DRC). Phytomedicine 7: 167-172.

Pellecuer, S., J. Allegrini \& M. Simeon de Bouchberg. 1976. Huiles essentielles bactericides et fongicides. Revue de l'Institut Pasteur de Lyon 9: 135-159.

Pérez, C. \& C. Anesini. 1994. In vitro antibacterial activity of Argentine folk medicinal plants against Salmonella typhi. J. Ethnopharmacol. 44: 41-46.

Pourmorad, F., S.J. Hosseinimehr \& N. Shahabimajd. 2006. Antioxidant activity, phenol and flavonoid contents of some selected Iranian medicinal plants. African J. Biotechnol. 5: 1142-1145.

Rabe, T. \& J. van Staden. 1997. Antibacterial activity of South African plants used for medicinal purposes. J. Ethnopharmacol. 56: 81-87. 
Rauha, J., S. Remes, M. Heinonen, A. Hopia, M. Kahkonen, T. Kujala, K. Pihlaja, H. Vuorela \& P. Vuorela. 2000. Antimicrobial effects of Finnish plant extracts containing flavonoids and other phenolic compounds. Int. J. Food Microbiol. 56: 3-12.

Saklani, S. \& S. Chandra. 2012. In vitro antimicrobial activity nutritional profile of medicinal plant of Garhwal, Himalaya. Int. J. Pharm. Sci. Res. 3: 268-272.

Sasidharan, S., I. Darah \& M.K.M. Jain-Noordin. 2009. Screening antimicrobial activity of various extracts of Gracilaria changii. Pharm. Biol. 47: 72-76.

Sastry, V.M.V.S. \& G.R.K. Rao. 1994. Antibacterial substance from marine algae: Successive extraction using benzene, chloroform and methanol. Bot. Mar. 37: 357-360.

Sawer, I.K., M.I. Berry \& J.L. Ford. 1997. Effect of medium composition, agitation and presence of EDTA on the antimicrobial activity of cryptolepine. Lett. Appl. Microbiol. 25: 207-211.

Sezik, E., F. Yeşilda, M. Tabata, G. Honda, Y. Takaishi, T. Fujita, T. Tanaka \& Y. Takeda. 1997. Traditional medicine in Turkey VIII. Folk medicine in East Anatolia Erzurum Ağrı, Kars, Iğdır provinces. Econ. Bot. 51: 195-211.
Shah, P.M. 2005. The need for new therapeutic agents: what is in the pipeline? Clin. Microbiol. Infec. Dis. 11: $36-42$.

Spellberg, B., J.H. Powers, E.P. Brass, L.G. Miller \& J.E. Edwards Jr. 2003. The trends in antimicrobial drug development: implications for the future. Clin. Infect. Dis. 38: 1279-1286.

Steenkamp, V., E. Mathivha, M.C. Gouws \& C.E.J. van Rensburg. 2004. Studies on antibacterial, antioxidant and fibroblast growth stimulation of wound healing remedies from South Africa. J. Ethnopharmacol. 95: 353-357.

Yang, Y.E., X.Q. Li \& C.P. Tang. 2008. Natural Products Chemistry Research 2006's Progress in China. Chinese J. Nat. Med. 6: 0070-0078.

Zhao, H.X., A.C. Rinaldi, A. Rufo, A. Bozzi, P.K.J. Kinnunen \& A. Di-Giulio. 2003. Structural and charge requirements for antimicrobial peptide insertioninto biological and model membranes, p. 151-177. In G. Menestrina, M. Dalla-Serra \& P. Lazarovici. (eds.). Pore Forming Peptides and Protein Toxins. Harwood, New York, USA. 